\title{
Medrese v. Üniversite Geri Kalmanın ve İlerlemenin Karşılaştırmalı Tarihçesi ${ }^{[*]}$
}

\author{
Gülşah TAŞÇI-KAYA ${ }^{[* *}$
}

Kitabın Adı : Medrese v. Üniversite Geri Kalmanın ve İlerlemenin Karşılaşıırmalı Tarihçesi

Yazarı : Kemal Gürüz

Yayınevi : Ka Kitap

Basım Yılı : 2016

Sayfa Sayısı : 360

ISBN : : 978-605-83915-9-8

Ka kitap tarafından yayınlanan Kemal Gürüz 'ün "Medrese v. Üniversite Geri Kalmanın ve İlerlemenin Karşılaştırmalı Tarihçesi” adlı eseri, Gürüz' ün üniversite rektörlüğü, TÜBİTAK Başkanlığı ve YÖK Başkanlığ gibi önemli stratejik görevlerde bulunduğu dönemlerde yükseköğretim tarihi üzerine yaptığı çalışmalar ve edindiği deneyimlerin bir araya getirilmesinden oluşmaktadır. ${ }^{1}$ Medrese ve üniversite karşılaştırmalı çalışmasına dayalı bu kitap, bir anlamda iki büyük dinin de karşılaştırmasına yönelik vurguları barındırmaktadır. Bu bağlamda kitap medrese ve üniversitenin ortaya çıkış süreçlerini tarihsel bağlamı içinde karşılaştırmalı ve kapsamlı bir şekilde ele almaktadır. Kitabın, medrese ve üniversiteye ait tarihsel arşivi ayrıntılı

[*] Bu değerlendirmenin son okumalarını yapan ve desteğini esirgemeyen Prof. Dr. Seyfi Kenan’a teşekkürlerimi borç bilirim.

${ }^{[* *}$ Doktora Öğrencisi, Marmara Üniversitesi, Eğitim Bilimleri Enstitüsü, Eğitim Yönetimi ve Denetimi, gulsahtasci@yahoo.com, gulsahtascikaya@marun.edu.tr

1 Bknz: Gürüz, Kemal, Türkiye’de ve Dünya’da Yükseköğretim, Bilim ve Teknoloji Raporu Üzerine Görüşler, TÜSİAD Yayınları No: T/95, 3-175, 1995; Gürüz, Kemal, "Yükseköğretimde Bilim ve Eğitim”, TÜBA Bilimsel ve Toplumsal Serisi:2 2002; Gürüz, Kemal, Dünyada ve Türkiye’de Yükseköğretim Tarihçe ve Bugünkü Sevk ve İdare Sistemleri, ÖSYM Yayınları, Ankara 2001; Gürüz, Kemal, Erdoğan Şuhubi, Celal Şengör, Kazım Türker ve Ersin Yurtsever, “Türkiye’de ve Dünyada Yükseköğretim”, Bilim ve Teknoloji, TÜSİAD Yayınları No: T/94, İstanbul. 1994. 
bir şekilde sunması, okuyucuya büyük bir kolaylık sağlarken, diğer yandan dipnotların arkada verilmiş olması okumayı zorlaştırmaktadır.

Kitap; (1) Tarihsel Perspektif, (2) Medrese İslamiyet’te Eğitim, (3) Orta Çă̆ Üniversitesi Tarihsel Arka Plan, (4) 1500-1800 Dönemi Hümanizm, Rönesans, Reform ve Birinci Bilimsel Devrimin Etkileri, (5) 1800'den Günümüze: Modern Üniversitenin Doğuşu ve Yükseköğretim Sistemleri olmak üzere toplam beş bölümden oluşmaktadır.

Birinci bölüm, medrese ve üniversite kavramlarını tarihsel bağlamı içinde anlamlandırırken, diğer yandan da ortaya çıkış süreci, kurumsal nitelikleri, benzerlikleri ve farklılıklarını daha kapsayıcı biçimde ele alarak Hristiyanlık dünyasında ve Müslümanlık âleminde eğitimi, dini ve tarihi bir zemine oturtmaktadır. Özellikle de üniversitelerin bir kurum olarak dünyaya yayılmasında rol oynayan tarikatları, kilise-devlet ilişkilerini ortaya koyarken, üniversitenin ortaya çıkışında uhrevi ve dünyevi bir iki kutuplu bir ortamda, nasıl bir üniversitenin oluştuğunu örneklerle desteklemektedir. Dolayısıyla, medrese ve üniversite arasındaki temel farkı da bu iki kutba atfetmektedir. Özellikle de papalık ve halifelik üzerine yaptığı karşılaştırmalar altı çizilen bir diğer noktadır. Dikkat çeken bir diğer nokta, Gürüz 'ün bu bölümde "İslam Rönesansı", aslında Horasan, Maveraünnehir ve Orta Asya Aydınlanması"dır (s.44) atfına yer vermesi ve bu dönemdeki bilimsel çalışmaların Arapların ürünü olarak görülmesini eleştirmesidir. Gürüz, bunu yaparken, tek bir kanıya göre yargıya varmaktadır. Dolayısıyla, tek bir görüşe göre bu kanıya varması okuyucuda soru işaretleri uyandırmaktadır. Diğer yandan, dünyadaki bazı örneklere gönderme yaparak İslam eğitiminde İbn-i Teymiyye’nin görüşlerinin sanki ülkemizde geniş bir yer bulacağı kaygısı göze çarpmaktadır. Ancak Gürüz, vardığı bu sonuç için herhangi bir referans vermemektedir.

Kitabın ikinci bölümü ise “ilim” ve "bilim” ayrımıyla başlamaktadır. Öyle ki bu noktada Gürüz, ilim, âlim-bilim insanı kelimelerinin eş anlamlı kullanılmasını eleştirmektedir. Diğer yandan, İslami eğitimin, İslami ilimleri kapsadığını, akli bilimlerin İslami bilimler içinde yer almadığını savunmaktadır. Oysaki bu tezleri Seyfi Kenan “Osmanlı Eğitim ve Düşünce Dünyası” ve “Modern Üniversitenin Oluşum Süreci” adlı çalışmalarında İslam dünyasında klasik dönemde şekillenen ilim anlayışında daha bütüncül bir ilim/bilim anlayışının var olduğunu ayrıntılı bir şekilde ele almaktadır. Söz gelimi Cambridge Üniversitesi üyeliğine kabul edilen Emin Paşa’nın (1840-1892) Fransızca kaleme aldığı matematik alanındaki dikkat çekici eserlerle modern matematik alanında Osmanlı Türklerinin devirlerini yakalama çabası içinde olduklarını gösterdiğini ifade etmektedir (Kenan, 2013, s.8). Hatta beşerî bilimlerin, George Makdisi’nin çalışmalarına dayanarak, ilk defa VII-VIII. yüzyıllarda İslâm dünyasının doğusunda teşekkül etmeye başladığına, daha sonra olgunlaşarak Mısır, Kuzey Afrika, Endülüs ve Sicilya’ya, oradan da Avrupa’ya geçtiğine dikkat çekmektedir (Kenan, 2015, s. 343).

Yine Gürüz İslami eğitimin sadece ezbere dayandığını ifade etmektedir. Oysaki bu iddiaya Kenan’n çalışmalarında $(2013,2015)$, ezberin eğitim sürecinde önemli bir yer tutmasının yanı sıra tekrar ve müzâkere yöntemiyle birlikte münazara yönteminin kullanıldığının altı çizilmekte ve en etkin öğretme ve öğrenme yöntemi olarak kullanılan hilaf ve cedel yöntemi gibi diyalektik 
yöntemin klasik dönem İslam eğitim-öğretim geleneğinde önemli bir yer tuttuğu görülmektedir. Hatta öyle ki bu yöntemle modern dönemde Darülfünun'da ders veren medreseli hocalar bile vardır (İhsanoğlu, 2010).

Kitaptaki önemli iddialardan biri, Endülüs'te yaratılan yüksek kültürün, medresenin varlığından tamamen bağımsız ortaya çıktığını belirtilmesidir. Oysaki bu durumda İslâm dünyasının ve medreselerin bazen dolaylı, bazen dolaysız etkisi var görünmektedir. Bu bölümde genişçe yer verilen konulardan biri de, Nizamiye Medreseleridir. Gürüz, Nizamiye Medreselerinin özellikleri ve eğitimin içeriği hakkında geniş bilgi verir. Buna ek olarak Gazali’nin medreseye olan katkılarının yanı sıra olumsuz etkileri ifade edilmektedir. Bu bölümde anlatılan bir diğer konu ise, Osmanlılarda eğitim ve Osmanlı medreseleridir. Bu bölümde dikkat çeken bir nokta "Fatih Külliyesi’nin kurumsal çatısı altında medreseyle birlikte akademik bir bütün oluşturduğu doğru değildir "(s.88) ifadesidir. Buna ek olarak Gürüz yukarıda da sıkça ifade edildiği gibi, bilimsel araştırma ve yayın faaliyetinin medresenin amacıyla ters olduğunu (s.96), akli bilimlerin hiçbir zaman medreselerin müfredatı içinde olmadığını iddia etmektedir. Ancak bu ifadelerin tarihçiler nezdinde tartışılır bir yanının olduğunu söylemek yerinde olacaktır. Bu teze cevaben ortaya konan çalışmaların göz ardı edildiği anlaşılmaktadır. Yine aynı bölümde Gürüz’ün bir Osmanlı aydını olarak Katip Çelebi'ye yer veren ifadeleri vardır. Bu bölümün son kısmında medreselerin çöküş nedenleri sıralanmış ve iki nedeni kapsamlı bir biçimde ele alınmıştır: İlki "Ferdiyetçilik ve bencillik", ikincisi ise "Arapça"dır.

Gürüz, üçüncü bölümde ise Orta Çağ Avrupa’sının tarihsel arka planına odaklanır. Orta Çağ Avrupası üniversitesinin klasik akademik yapısını, modellerini, içerik ve kullanılan yöntemleri örneklendirerek gösterir. Bunun yanı sıra bu bölümde Nizamiye Medreseleri ile Orta Çağ Avrupası üniversitelerinin karşılaştırmaları yer almaktadır. Dahası, Gürüz bu bölümde üniversiteyi insan aklını ön plana aldığını gösterirken, diğer yandan medreseyi vahiy odaklı bir çerçevede göstermektedir. Oysaki medreseler, "XI. yüzylldan itibaren hem İslâm dünyasının çeşitli bölgelerinde hem de Avrupada yüksek eğitimin gerek kurumsallaşma gerek ders içeriklerinin şekillenmesinde önemli katkılar yapmıştır" (Kenan, 2015,s.334). Bu nedenle medresenin görünenin aksine katkıları yadsınamaz.

Dördüncü bölüm Orta Çağ üniversitesinin, kilisenin etkisi azaldıkça zamanla nasıl da modern üniversiteye dönüștüğünü, kaostan Hümanizmaya, Aydınlanmaya doğru nasıl ilerlediğini ve bu süreçte etkili olan olayları tarihsel bağlamı içinde ele almıştır. Bunu yaparken dönemin ünlü felsefecileri ve bilim adamlarına yönelik atıflarla bölüm zenginleştirilmiştir. Bu bölümde ayrıca üniversitenin Avrupa’da yayılmasılyla meydana gelen gelişmeler, yine bu dönemde ortaya çıan bilim akademileri ve bilimsel derneklerle, mektup, kitap ve dergilerden oluşan bilimsel yayınların ortaya çıkışından bahsedilmektedir. Bunun yanı sıra, üniversitelerin sanayi devrimiyle beraber kolonistler, tarikatlar ve göçmenler vasıtası ile yayılmasını anlatılmaktadır. Zira Kuzey Amerika’ya giden göçmenlerin bu yayılmada etkisi büyüktür. Özellikle de ABD'de kurulan üniversitelerin katkılarından birini "eğitim yoluyla topluma hizmet" (s.218) olarak adlandırır ve bu dönemdeki üniversiteleri toplumsal kurum olarak görür. 
Beşinci bölüm 1800'den günümüze modern üniversitenin doğuşunu ve yükseköğretim sistemlerini ele alırken Napolyon döneminin üniversitenin kaderi üzerindeki etkilerine değinmekte, Wilhelm von Humboldt'un “Bildung ideali”ne ve araştırma üniversitesinin temellerinin atıldığı entelektüel ortama nasıl gelindiğini, felsefi alt yapısını göstererek irdelemektedir. $\mathrm{Bu}$ irdelemeyi yaparken de bir modern üniversite formu olan Humboldt modelini “Alman Dehâsı’nın insanlığa armağanıdır" (s.233) sözüyle öne çıkarmaktadır. İlerleyen başlıklarda ise yeni tür üniversite ve yapılarını ülkeler nezdinde değerlendirmektedir. Özellikle de Modern Amerikan üniversitelerin doğuşunu ve Amerikan yükseköğretim sistemini şekillendiren eğilimleri, akreditasyon sisteminin başlangıcını, araştırmanın üniversitenin işlevlerinden biri haline geldiğini, Amerikan üniversitelerinin getirdikleri yenilikleri, kitleselleşmesini, gelişmiş ülkelerde ise nasıl evrenselleştiğini ve küreselleşmenin yansımalarını ayrıntılı bir şekilde ele almaktadır. Bu noktada Gürüz’ün, Altbach'dan yaptığı alıntı dikkate değerdir: "Amerikan araştırma üniversiteleri gerçekten bir liberal arts kolejinin üstüne eklemlenmiş Alman üniversitesi gibidir” (s.255). Zira Gürüz’ e göre liberal arts koleji hüviyetindeki Amerikan üniversiteleri, Almanya’dan dönen öğrencilerin etkisiyle oluşmuştur ve modern üniversitelerin doğuşunda liberal arts kolejlerinin etkisi büyüktür.

Son olarak Gürüz, kapatış cümlelerinde medresenin nasıl olup da medeni dünyadan silindiğini sorgular. Ve bunu "nedensellik ilkesinin yokluğuna ve insan aklına dayalı düşünüş tarzının” olmamasına bağlar.

Sonuç olarak kitabın, medrese ve üniversite konusunu ayrıntılı olarak ele almasına rağmen, konuyu tek odaklı bir sacayağına oturtması kitaptaki en belirgin sıkıntıdır. Dolayısıyla, Gürüz’ün sadece medresenin eksikliklerini ortaya çıkarmaya çalışması ve katkılarını görmezden gelmesi bu çalışmanın sınırlılıkları arasında görülebilir. Kitabın içindeki alıntılarda da görüldügüu üzere, medrese ve üniversiteye ilişkin analizleri, medreseyi taşa tutmaktan öteye geçememektedir. Zira bilim ileriye ufuk açarak genişler. Oysaki bu kitapta, bazı geri kalmışlıklar sadece toplumsal kurumlardan bir olan eğitime ve bir eğitim kurumu modeli olan Medreseye atfedilerek, geçmişe bir haksızlık yapılmaktadır. Bu türden bir yok sayma yerine Türkiye’nin tarihsel bağlamı içinde yaratıcı bir çözüm bulmak ya da bütünsel bakış açısı kazanmak yükseköğretim sisteminin gelişimi bakımından daha faydalı sonuçlar doğuracaktır. Son kertede kitap, sınırlılıklarına rağmen üniversite ve medrese ikiliği üzerine yazılmış ilk kitaplardan biri olmasının yanında, ayrıntılı alıntılara dayanan yönüyle okuyucuyu araştırmaya sevk etmekte ve merak uyandırmaktadır. Üniversite ve medrese üzerine araştırmacılara zengin bir içerik sunmaktadır. 


\section{Kaynaklar}

Gürüz, K., Şuhubi, E., Şengör, C., Türker, K. ve Yurtsever, E. (1994). Türkiye’de ve Dünya’da Yükseköğretim, Bilim ve Teknoloji, TÜSİAD Yayınları No: T/94, İstanbul.

Gürüz, K.(1995). Türkiye’de ve Dünyada Yükseköğretim, Bilim ve Teknoloji Raporu Üzerine Görüşler, TÜSİAD Yayınları No: T/95, 3-175.

Gürüz, K. (2001). Dünyada ve Türkiye’de Yükseköğretim Tarihçe ve Bugünkü Sevk ve İdare Sistemleri, ÖSYM Yayınları, Ankara 2001.

Gürüz, K. (2002). Yükseköğretimde Bilim ve Eğitim, TÜBA Bilimsel ve Toplumsal Serisi: 2.

İhsanoğlu, E. (2010). Darülfünun: Osmanlı'da kültürel modernleşmenin odağı (iki cilt). İstanbul: IRCICA, I-II.

Kenan, S. (2013). Türk Eğitim Düşüncesi ve Deneyiminin Dönüm Noktaları Üzerine Bir Çözümleme, Osmanlı Araştırmaları: The Journal of Ottoman Studies Misafir Ed. S. Kenan, 41, s.1-32.

Kenan, S. (2015). Modern Üniversitenin Oluşum Süreci, Osmanlı Araştırmaları / The Journal of Ottoman Studies, XLV, s.333-367. 